\title{
Examining the Effect of Empowerment, Teamwork and Training on Employee Satisfaction in the Headquarters of the Tehran Social Security Organization
}

\author{
Halimeh Eskandari, \\ Master science of executive management, \\ Iranian Social Security Organization \\ AttiehS.Mirakbari \\ Master science of executive management, \\ Iranian Social Security Organization, \\ E-mail: ea.mirakbari@gmail.com
}

Received: Jun. 3, 2019 Accepted: Oct. 1, 2019 Online published: Oct. 28, 2019

doi:10.5296/ijhrs.v9i4.14882ＵRL: https://doi.org/10.5296/ijhrs.v9i4.14882

\begin{abstract}
The status and role of human resources in the progress and development of the organization as the main source of the organization is of great importance and credit. Here, job satisfaction is more and more sought after by senior managers of the organizations. Thus, it is important to develop proper policies and plans for decision makers about the factors effective in increasing job satisfaction of employees. Thus, the purpose of this paper was to investigate the effect of empowerment, teamwork and education on job satisfaction of employees at the headquarters of the Tehran Social Security Organization. The research method was descriptive-correlational and the population was 1200 employees of the headquarters of the Social Security Organization (HSSO). Of these, 305 were selected based on Cochran's formula by simple random sampling. According to the Kemo and Bartlett test done, the research data are of sufficient reliability, so for analyzing the assumptions of the research, factor analysis and structural equation modeling tests were used with the help of SPSS21 and LISREL 8.83 software. The results of the research indicated that empowerment of employees, teamwork, and education had a positive and significant effect on job satisfaction. In addition, staff training and teamwork have a positive and significant effect on employee empowerment.
\end{abstract}


Keywords: Empowerment, Teamwork, Staff Training, Job Satisfaction

\section{Introduction}

The most important capital and competitive tools of any organization in providing better services to customers are its employees, so the recognition of their job satisfaction is essential. Job Satisfaction is one of the most important issues in research and organizational studies, appreciated particularly since the 1920s. Job satisfaction, due to the complexity and multidimensionality of the intersection and the common structure of many scientific fields, and there are numerous and sometimes complex concepts of it (Eidipour \& Zarei, 2016). Empowerment is an effective strategy by using which an organization improves the capabilities and responsibilities of its employees, because in general it is obvious that if an employee is empowered, he will be more effective in fulfilling his duties.

Empowerment, teamwork, agility, education, and learning, empowerment are of the key strategies for developing organizations to adapt to external change and one of the main issues of organizations. Nowadays, these concepts are seen as tools by using which managers can manage today's organizations that have features such as the diversity of penetration channels, growth, reliance on horizontal and network structures, minimizing the staffing distance from managers, and reducing the organization's belonging, and using information technology efficiently (Baloh \& Trkman, 2003). It also helps employees master their knowledge, skills and behavior, and achieve a sense of value and self-confidence to perform effectively and efficiently tasks to improve organizational performance. As a result, investing in the training and development of group activities among employees could lead to more favorable positions and status in the organization for them and give them the satisfaction (Sultana, Sobia, Ahmed, $\&$ Mehmood, 2012). Therefore, according to the presented points, this study seeks to investigate the effect of empowerment, teamwork and education on job satisfaction of employees.

\section{Theoretical Basics of Research}

\subsection{Empowering Employees}

The term empowerment in its special sense is giving power and giving people freedom to act for their own administration and in the organizational sense means changing culture and giving courage in creating and directing an organizational environment. In other words, empowerment is the design and construction of an organization so that individuals are more willing to assume more responsibilities while controlling themselves. Empowering creates intelligent, brave, honest, and reliable employees abilities to control their work life and develop sufficiently to take on more responsibilities in the future (Nagendra \& Deshpande, 2014)

The empowerment theory has a very high appeal. According to this theory, all people in the world love democracy, freedom and justice. If this is the case, then why is there not real empowerment in many work environments where democracy and total freedom are dominant? Since many organizations operate independently of governments in their decisions, there is always a difference between values such as equality justice and powers authority, and these 
differences have spread of the organization. Thus, it can be stated that many values, such as leadership methods and ethical values are specific to working environments in an organizational culture that affects the entire organization (Singh, 2016). The concept of empowerment is something more than just the right at work, and managers must work with some aspects (pleasurable) to achieve the goals of the organization. If their managers, state that they have empowered their employees, they should not hope that actual ability has taken place unless those third parties provide the truth as managers do not explain the facts in their assessments of employees' work. In any case, the leaders cannot succeed unless they are sympathetic to them and motivate them to be spiritually enthusiastic and to be honest, loyal and realistic with them. They must be honest at the first step (Sepehr \& Vesal Azad, 2016).

\subsubsection{Empowerment Models}

\subsubsection{Robbins, Crino, \& Fredendall's Empowerment Model}

According to these three researchers, although in many studies, empowerment has been defined as an instinctive stimulus or individual response to an instinctive stimulus, in fact, empowering is the acceptance of a particular plan; acceptance of the new structure of the occupation, transfer of power, conferral of authority, participation in information and participation in information and in resources. The three researchers believe that by focusing on environmental factors and individual elements, one can achieve the best of the empowerment process. The most basic step in this process is to create a wider range of internal working environments to create an opportunity to tap into all areas of empowerment and motivate them to advance its (Robbins, Crino, \& Fredendall, 2003;420)

\subsubsection{Bowen \& Lowler's Empowerment Model}

Bowen \& Lowler (1992) consider empowerment as the only strategy for including employees more and more in power. In the empowerment model of these two researchers, access to information plays an important role in decision-making (Bowen \& Lawler, 1992;31)

\subsubsection{Mc lagan \& Nel's Empowerment Model}

McLagan \& Nel, (1995) have proposed a multi-dimensional approach to employee empowerment. Mc Lagan believes empowering individuals empowers their responsibilities and responsibilities to other levels of organization that directly coordinates their partners to solve the problem (McLagan \& Nel, 1995;122)

\subsubsection{Gao's Empowerment Model}

Gao Institution (2001), acting on behalf of the Senate State Committee on Government Affairs conducted a research entitled Human Capital, which took measures to empower employees. The institute targeted five US agencies or firms and analyzed all of these agencies' efforts to empower them. The Institute has presented its study results in six basic steps for empowering employees, and believes that shifting attention to empowering employees and engaging them in administration makes it easier to make changes (Mihm, 2001). 


\subsection{Teamwork}

According to Goldstein (1984), a team or group can be referred to as two or more individuals with interactions and dependencies that work together to achieve a specific goal. On the other hand, a team is a type of group. A team can be referred to a group of people with complementary skills committed to a specific goals and have a mutual responsibility to perform a set of goals or tasks (Soltani, 2016). In the definition of working teams, it should be said that a set of two or more individuals that has a dynamic, interdependent, and coordinated interaction for a purpose or shared values, and also has complementary roles or skills for these purposes (Arefi, Shuhudi, \& Zandi, 2012 \& Fapohunda, 2013).

Different researchers have considered different aspects of teamwork. For example, Hoegl \& Parboteeah, (2007) have identified six dimensions of communication, coordination, balance of assistants, mutual support, effort, and coherence to examine the quality of teamwork. Baker, Amodeo, Krokos, Slonim, \& Herrera, (2010) have outlined four dimensions of status monitoring, mutual support, leadership, and communication for teamwork skills.

Hoegl \& Gemuenden, (2001) examined the six dimensions of communication, coordination, balance of assistance, mutual support, effort, and coherence to assess the quality of teamwork. Baker, Horvath, Campion, \& Salas, (2005) considered four dimensions of group decision making and planning, adaptability and flexibility, interpersonal relationships, and communication for teamwork. Finally, Lencioni, (2002) has put forward four dimensions of commitment, trust, constructive, and targeted attitude to measuring teamwork. Based on Lencioni's view and according to available basis, four of the following dimensions are considered for measuring teamwork:

- Commitment: commitment is to adhere to the decisions and plans, so that everyone clearly contributes to them, as though the decision was unanimously taken.

- Trust: The team members' goodwill and confidence in the team's trust and confidence are that they do not need to take care of their defenses.

- The constructive approach is a constructive debate in which people get the best in the shortest time.

- Purposefulness is a situation in which individuals prefer team target to individual needs and goals (Lencioni, 2002).

\subsubsection{Advantages of Using Work Teams in Organizations}

Griffin states that the use of teams will have the following benefits:

- Benefits for employees: Freedom of employees in teams allows them to grow and earn profits through self-management.

- Benefits for the organization: Increasing performance and improving interoperability among the members lead to increased innovation, creativity and flexibility, which, given the current complex environment, lead to organizational effectiveness (Moorhead \&Griffin, 2013). 


\subsubsection{Staff Training}

Nadler (1984) distinguishes between the three concepts of education, training and development in the field of learning topics:

-Training is the learning of topics related to the current job.

-Education is learning to prepare for people who are not related to a particular job now and in the future.

-Development or improvement is learning to grow a person who is not related to the current or future occupation (Wilson, 2004; 8).

According to Phillippo, education is an attempt to increase the knowledge and skills of employees to carry out certain occupations. An important output of training is learning. A trainee trains new habits, learn skills and useful knowledge to help him improve his job performance. Training enables the staff to perform the current job more efficiently and prepare themselves for a higher level job (Abtahi, 1994; 17).

Training and job capability are of the most complex tasks in managing each organization's affairs, especially in manpower management. After the recruiting system, there is a system of improvement and proper utilization of human resources. In fact, education is one of the most important actions and programs of each organization and the educational system complements the employment system and enhances the existing human resources and future achievements. Education and refinement will lead to a deeper insight and appreciation of the higher knowledge and ability and skill of the people employed in the organization to perform the assigned tasks and thereby achieve better and more effective organizational goals (Tabatabaee, 2004).

\subsubsection{Job Satisfaction}

Job satisfaction is the inner consciousness and attitude of the individual towards the job and this is the result of the multidimensional interaction between the individual and the environment (Chen et al., 2014). Job Satisfaction is conceptualized as a multidimensional structure, which includes satisfaction from the individual manager, colleagues, salaries, degree promotion opportunities, job security, and company policies (Avery, Smillie, \& Fife-Schaw, 2015). Job satisfaction is defined as the pleasurable emotional state resulting from a person's job evaluation as achieving or facilitating the attainment of individual occupational values. Job satisfaction is the result of job expectations and experiences, and is very personal and subjective. If the difference between expectations and experience is low, the satisfaction level will be high and vice versa (Pan, 2015).

Job Satisfaction can be derived from job satisfaction based on expectations and satisfaction with the performance of the individual. Job satisfaction is based on expectations of employee satisfaction with regard to whether a person feels that his job expectations are at his current position and that he is satisfied with the balance between expectations and emphasizes perceived reality for all aspects of the work involved. Satisfaction with the performance of a person is related to the extent to which an individual is satisfied with his or her own 
performance. The satisfaction scores of a person's work performance was previously used in laboratory environments where the satisfaction of an individual's performance often increased linearly during a laboratory work period and the amount of satisfaction with a person's performance more under cognitive-burden conditions low, relative, or high-frequency reports were reported (Avery et al., 2015). In evaluating the factors affecting employee satisfaction, the factors commonly found in job desirability, organizational commitment, individual fitness, job satisfaction and work-related stress is discussed. The results show a positive relationship between the components of organizational commitment, the components of individual fit with the organization, the components of job satisfaction and organizational justice with job satisfaction, and a negative relationship between the components of the stresses of the work environment and the willingness to job satisfaction (Zamani et al , 2014).

\section{Theoretical Framework and Conceptual Model of Research}

Job satisfaction is a topic that many studies have been done in various areas. The increasing number of researchers in this area reveals the importance of this. Furthermore, job satisfaction is one of the key variables affecting organizational success and necessary to pay close attention to its negative effects on organizational performance (Bakotić \& Babić, 2013).

Wellins, Byham, \& Wilson, (1991) noted that an organization that emphasizes the empowerment of employees could survive in the end. Empowerment creates a sense of being effective in the staff and feels ownership of their work, and strengthens the focus of self-control. This understanding of their effectiveness is accompanied by a sense of satisfaction. In their research, they found a direct and significant relationship between empowerment and job satisfaction.

Teamwork is an important concept in organizational behavior. Khuong \& Tien (2013)defined teamwork as a process for organizing groups among employees to conduct a particular task. Thus, teamwork is a kind of mutual and participatory event designed to achieve a specific goal. They pointed out that teamwork had a significant and positive effect on job satisfaction (Khuong \& Tien, 2013).

Staff training is an important factor affecting employee behavior (Schmidt, 2004). Recent studies have concluded that training has a positive effect on job satisfaction (Khuong \& Tien, 2013). Additionally, Adesola, Oyeniyi, \& Adeyemi, (2013) reported that training has a positive effect on job satisfaction. Based on the above, it can be understood that various researchers have found evidence of a positive relationship between employee training and job satisfaction. In the results of this study by Hanaysha \& Tahir, (2016), it can be deduced that three variables of empowerment, teamwork, and training have had a significant and positive effect on employees' job satisfaction.

All research studies are based on a conceptual framework that identifies the variables and relationships between them. Since each field research needs a mental map and a conceptual model presented in the form of an appropriate analytical tool, the variables and relationships between them are mapped. In this research, the 


\section{Macrothink}

International Journal of Human Resource Studies

ISSN 2162-3058 2019, Vol. 9, No. 4

conceptual model of Hanaysha \& Tahir, (2016) has been used to achieve the research objectives. According to this research - the effect of staff empowerment, teamwork and employee training on job satisfaction of employees in the headquarters of the Social Security Organization is analyzed - the conceptual and analytical model of the research consists of two parts: empowerment of employees, teamwork and staff training (independent variables) and job satisfaction (dependent variable) as presented below.

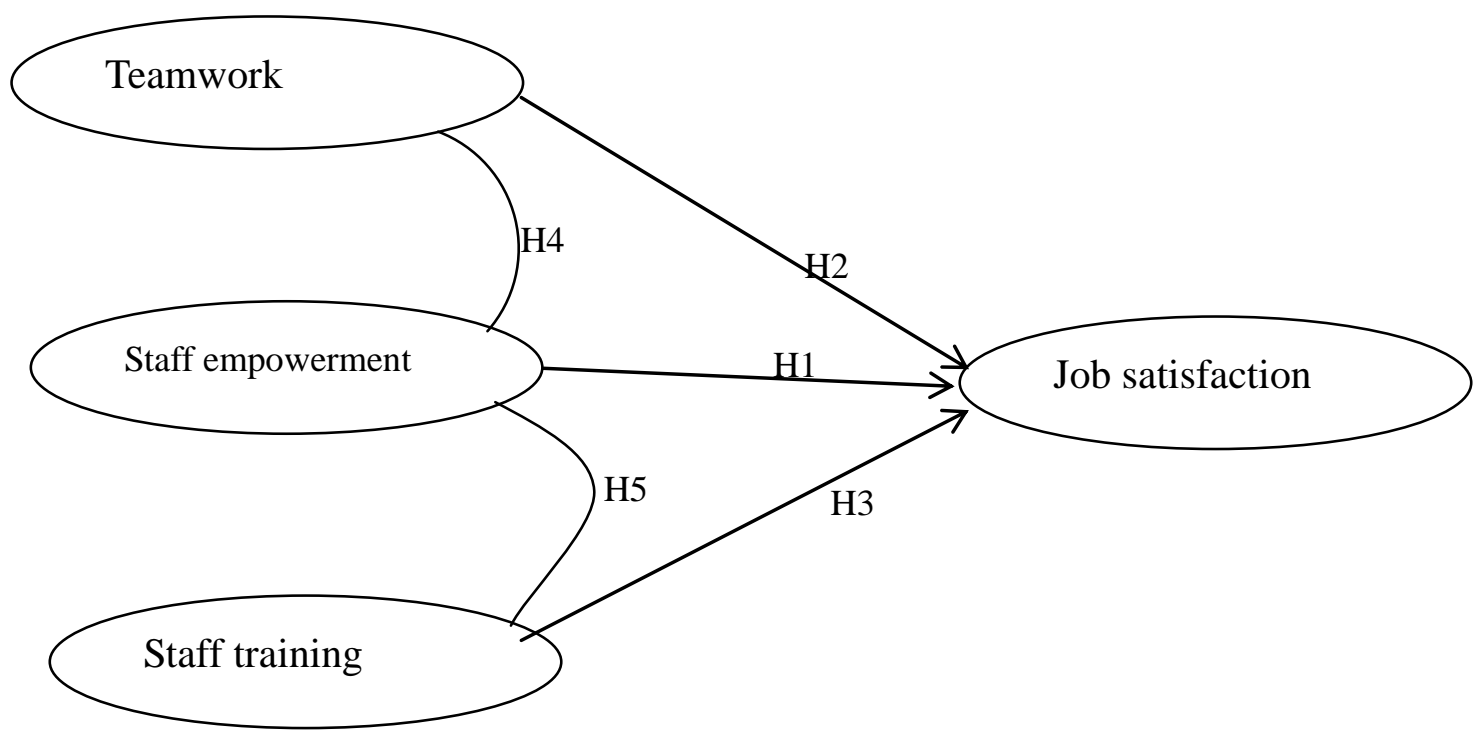

Figure 1. Conceptual model of research adapted from the Hanaysha \& Tair's model

According to the conceptual model, the research hypotheses are presented as follows:

H1: Empowerment of employees has a significant and positive effect on job satisfaction of employees.

H2: Teamwork has a significant positive effect on employee satisfaction.

H3: Staff training has a significant and positive effect on employees' job satisfaction.

H4: Teamwork has a significant and positive effect on the empowerment of employees.

H5: Staff training has a significant and positive effect on employee empowerment.

\section{Methodology}

The present research was applied regarding the purpose, and in terms of collecting the required data, it is a correlation (considering that the relationship between the variables of the research is analyzed based on the research purpose) of a descriptive research. Among the correlation research methods, this study is considered as the structural equation modeling as structural equations model is used to test structural relationships based on the existing research findings. The population of this research was all employees of the headquarters of 
Social Security Organization in Tehran. The population of the study was 1200 people who were selected according to the Cochran formula as 291 to resolve the effects of the missing and incomplete questionnaires of unanswered questionnaires on the results of the research, the sample size increased from 291 to 320 . Finally, as some of the respondents had refused to answer some of the items, 15 questionnaires were deleted from the final analysis and 305 questionnaires were analyzed. Thus, it can be stated that the rate of use of the questionnaires was approximately 96\%. The tool for data collection was the Hanaysha \& Tahir, (2016) questionnaire with 20 questions, whose validity and reliability were confirmed in the research. The measures used in the operational development of the structures were modified and developed in accordance with the theoretical framework of the research as well as previous research and finally used in the research questionnaire. All measures were in the form of a five-option Likert scale measured with a range of full agreement to full disagreement.

In this research, confirmatory factor analysis (Hu \& Bentler, 1999) was used to assess the characteristics of the measures related to the existing structures and the fitness indices (GFI, NNFI, CFI, NFI) were measured and tested, which was more than the threshold level (0.90) recommended in research texts (Hair, J.F., Black, W.C., Babin, B.J., Anderson, 2014)

The combined coefficient was also evaluated by calculating the Cronbach's alpha coefficient. This coefficient for the information technology and knowledge management questionnaires was 0.819 and 0.889 , respectively. To analyze the data, two methods of testing the theoretical model using techniques Structural equations modeling in LISREL 8.73 and the mean of a population test and Friedman test were used to examine the status of variables and their ranking in the target population using SPSS 21 software.

\section{Results}

\subsection{Descriptive Statistics}

The results of the descriptive statistics showed that $48.2 \%$ of the respondents were male and $51.8 \%$ were female. Approximately $22.6 \%$ were in the age group of less than 30 years, $52.5 \%$ in the age group of $31-40$ and $24.9 \%$ in 41 years and older. In terms of the level of education, $4.6 \%$ of the respondents had diploma, associate's degree, $14.4 \%$ had undergraduate education and $81 \%$ had graduated and postgraduate education. Considering work history, most respondents had work experience between 11 and 20 years.

\subsection{Validity and Reliability}

Table 1 shows the results of confirmatory factor analysis of independent and dependent variables and indicates a high degree of compatibility between measured measures and related structures and expected relationships. Considering t-value of research questions, all of them were approved (95\% significance level beyond the range (1.96, -1.96). In addition, the results of Cronbach's alpha test are presented in the following table to examine the reliability of the research variables. 
Table 1. Confirmatory factor analysis results and reliability coefficient for research variables

\begin{tabular}{lccc}
\hline Variable & $\begin{array}{c}\text { Loading } \\
\text { factor }\end{array}$ & t-value & Cronbach's alpha \\
\hline EMP & $0 / 89$ & $23 / 87$ & $0 / 893$ \\
EMP1 & $0 / 93$ & $14 / 83$ & \\
EMP2 & $0 / 71$ & $13 / 10$ & \\
EMP3 & $0 / 65$ & $17 / 18$ & \\
EMP4 & $0 / 77$ & ---- & \\
EMP5 & & & \\
TW & $0 / 91$ & $20 / 42$ & \\
TW1 & $0 / 96$ & $22 / 54$ & \\
TW2 & $0 / 77$ & $15 / 69$ & \\
TW3 & $0 / 93$ & $21 / 48$ & \\
TW4 & $0 / 75$ & $15 / 37$ & \\
TW5 & $0 / 67$ & $12 / 96$ & \\
TW6 & & & \\
TRA & $0 / 83$ & $17 / 55$ & \\
TRA1 & $0 / 77$ & $15 / 64$ & \\
TRA2 & $0 / 88$ & $19 / 16$ & \\
TRA3 & $0 / 92$ & $20 / 72$ & \\
TRA4 & $0 / 79$ & $16 / 20$ & \\
TRA5 & & & \\
JS & $0 / 843$ \\
JS1 & $0 / 88$ & $15 / 57$ & \\
JS2 & $13 / 50$ & \\
JS3 & $10 / 37$ & \\
JS4 & & & \\
& $0 / 6$ & \\
\hline
\end{tabular}

\subsection{Structural Model Test}

Structural equation modeling was used to test the research hypotheses. As the results in Table 5 shows, the fitness indices obtained for the structural model (RMSEA $=0.072, \mathrm{GFI}=0.95$, $\left.\mathrm{NFI}=0.96, \mathrm{CFI}=0.93=\mathrm{NNFI}=0.94, \mathrm{X}^{2}=470.43, \mathrm{df}=164, \mathrm{X}^{2 /} \mathrm{df}=2.87\right)$ implies a very good fit of the model.

Table 2. Fit indices for the research model

\begin{tabular}{ccc}
\hline Structural model & Recommended criteria & Fit index \\
\hline $470 / 43$ & $p \geq 0.05$ & $\underline{\chi}_{2}^{2}$ \\
$2 / 87$ & Less than 3 & $\frac{\mathcal{\chi}^{2}}{\mathrm{GFI}}$ \\
$0 / 95$ & Larger than or equal to 0.90 & NNFI \\
$0 / 94$ & Larger than or equal to 0.90 & CFI \\
$0 / 93$ & Larger than or equal to 0.90 & RMSEA \\
$0 / 072$ & Smaller than or equal to 0.08 & NFI \\
$0 / 96$ & Larger than or equal to 0.90 &
\end{tabular}




\section{Macrothink}

International Journal of Human Resource Studies

ISSN 2162-3058

2019, Vol. 9, No. 4

After determining the measurement models to evaluate the conceptual model of the research and to ensure the existence or non-existence of a causal relation between the research variables and its related measures, and to examine the appropriateness of the observed data with the conceptual model of the research, the research hypotheses were also tested using structural equation models. The software outputs are presented in both standard and meaningful parameters in Figures 2 and 3.

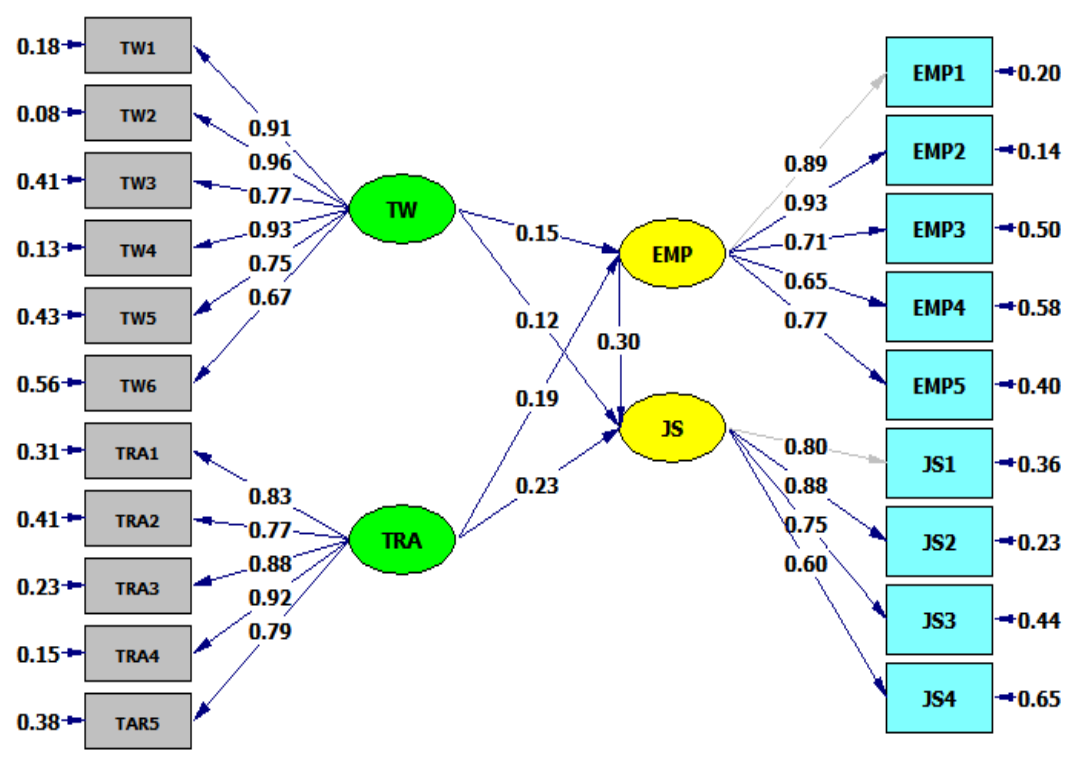

Chi-Square $=470.43, \mathrm{df}=164$, P-value $=0.00000$, RMSEA $=0.072$

Figure 2. Measuring the general model and the results of the hypotheses in the standard state

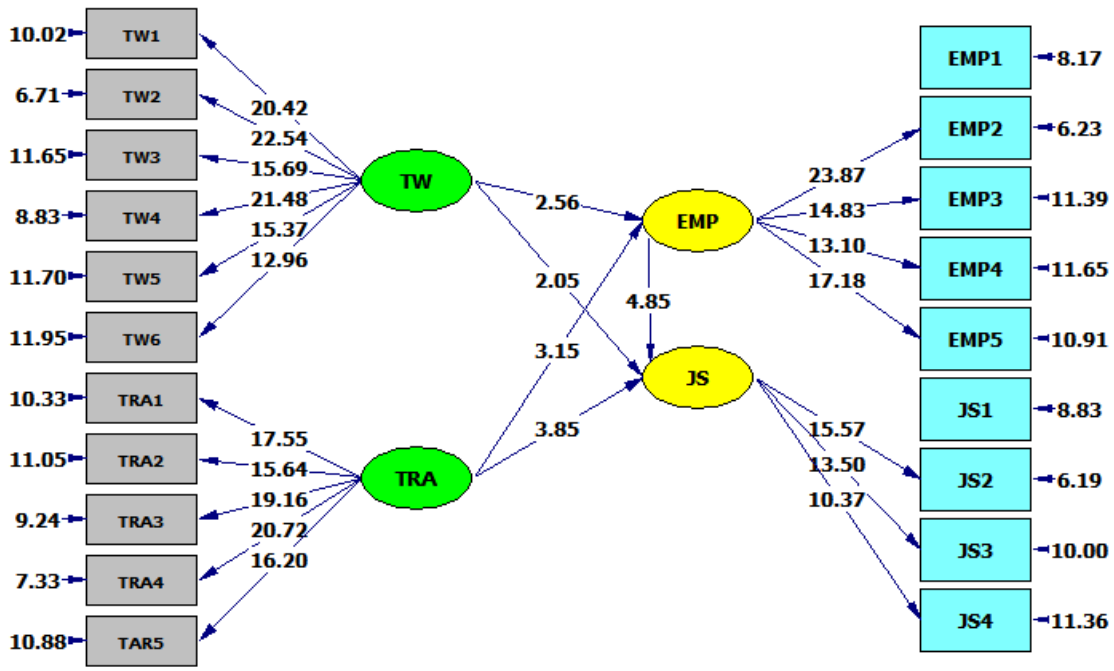

Chi-Square $=470.43, \mathrm{df}=164$, P-value $=0.00000$, RMSEA $=0.072$

Figure 3. Measurement of the general model and the results of the hypotheses in the meaningful state of the parameters

The results of testing the hypotheses with respect to the relationships to the variables in the 
output of the software are summarized in Table 2 below.

Table 3. Results of research hypotheses

\begin{tabular}{|c|c|c|c|c|}
\hline Row & Hypotheses & $\begin{array}{l}\text { Standard } \\
\text { coefficient }\end{array}$ & Sig. & $\begin{array}{l}\text { Test } \\
\text { results }\end{array}$ \\
\hline H1 & $\begin{array}{l}\text { Empowerment of employees has a } \\
\text { significant and positive effect on job } \\
\text { satisfaction of employees. }\end{array}$ & $0 / 30$ & $4 / 85$ & confirmed \\
\hline $\mathrm{H} 2$ & $\begin{array}{l}\text { Teamwork has a significant positive effect } \\
\text { on employee satisfaction. }\end{array}$ & $0 / 12$ & $2 / 05$ & confirmed \\
\hline $\mathrm{H} 3$ & $\begin{array}{l}\text { Staff training has a significant and positive } \\
\text { effect on employees' job satisfaction. }\end{array}$ & $0 / 23$ & $3 / 85$ & confirmed \\
\hline $\mathrm{H} 4$ & $\begin{array}{l}\text { Teamwork has a significant and positive } \\
\text { effect on the empowerment of employees. }\end{array}$ & $0 / 15$ & $2 / 56$ & confirmed \\
\hline H5 & $\begin{array}{l}\text { Staff training has a significant and positive } \\
\text { effect on employee empowerment. }\end{array}$ & $0 / 19$ & $3 / 15$ & confirmed \\
\hline
\end{tabular}

As is seen in Table 2, all the research hypotheses have been confirmed. The standard coefficient for all positive relationships and meaningful numbers for all hypotheses is at a significant level of $95 \%$ outside the range $(1.96,-1.96)$. Thus, all the relationships have been confirmed.

\section{Conclusions and Suggestions}

The status and role of human resources in the progress and development of the organization as the main source of the organization is of great importance and credit. Here, job satisfaction is more and more sought after by senior managers of the organizations. Job Satisfaction is conceptualized as a multidimensional structure involving individual satisfaction from the manager, colleagues, rights, degree, promotion opportunities, job security, and organizational weaknesses (Avery et al., 2015). Thus, it can be stated that when the organization's employees perceive organizational satisfaction, it becomes easier to achieve the goals of the organization. In this regard, several researchers are seeking to identify factors affecting employee job satisfaction. There is much empirical evidence that employee empowerment, training, and teamwork are important and effective factors in increasing productivity and job satisfaction. According to the presented materials, we will review the results of the research:

In the first hypothesis of the research, "Empowerment has a positive and significant effect on job satisfaction of the headquarters staff of the Social Security Organization," statistical analysis showed that the hypothesis was confirmed. Moreover, in confirming the acceptance 
of the hypothesis based on theoretical studies and theoretical knowledge with comparative comparisons between the present research and similar studies from the researches of Eidipour and Zarei (2016), Moradi Mahaneh (2016), Dabaghi et al. (2014), Hanaysha \& Tahir, (2016) and Fiori, Bollmann, \& Rossier, (2015), which confirmed the results of this study. Thus, it is suggested that in the Social Security Organization, the structure of the organization should be designed in such a way that the power and authority of the necessary decisions are delegated to the employees to assign tasks. Moreover, managers should pay special attention to build trust and organizational trust and strengthen it in the organization. In addition, in the tasks of the organization's occupations and organizational posts, it is necessary to pay attention to the abilities of individuals in their work.

The second hypothesis of the research stated that "Teamwork has a positive and significant effect on the job satisfaction of the staff of the headquarters of the Social Security Organization," which was confirmed and concluded that there is a meaningful relationship between teamwork and job satisfaction. In confirmation of acceptance of the hypothesis based on theoretical studies and theoretical knowledge, comparative comparisons were made between the present research and similar researches by Mirzai \& Fathi, (2013) and Hanaysha \& Tahir (2016), Kabak, Şen, Göçer, Küçüksöylemez, \& Tuncer, (2014) Bin Abdullah, Musa, Zahari, Rahman, \& Khalid, (2011) which confirmed the results of this study. Therefore, it is recommended that decision makers take into consideration the organizational structure of the work teams and consider incentives for successful teams. Managers of the organization should use management practices that enhance teamwork and employee participation in organizational decision-making. Finally, to strengthen teamwork, it is possible to use the participatory management system and the system of suggestions for the managers of the organization.

In the third hypothesis, the relationship between employee training and job satisfaction in the headquarters of the Social Security Organization was examined and the hypothesis was confirmed. We concluded that there is a significant relationship between employee training and job satisfaction and its effect is direct. In confirmation of acceptance of the hypothesis based on theoretical studies and theoretical knowledge, we used comparisons between the present research and similar researches from Sharafi \& Bahar (2016), Mirzai \& Fathi, (2013) Mousavi (2009), Hanaysha \& Tahir, (2016), Bin Abdullah et al,(2011), which confirmed the results of this study. Therefore, it is recommended that the officials of the Social Security Organization pay special attention to the organization's strategies for continuing education and human resource development. In addition, designing and implementing in-service training programs are recommended to raise the level of knowledge and awareness, technical and professional skills, and also the creation of favorable behavior of the staff.

In the fourth hypothesis, it was stated that "Teamwork has a positive and significant effect on the empowerment of the staff of the headquarters of the Social Security Organization", which was confirmed, and we concluded a meaningful relationship between teamwork and employee empowerment with direct effects. In confirmation of acceptance of the hypothesis based on theoretical studies and theoretical knowledge, we made comparisons between the present research and similar studies of Soltani (2016), Askarzadeh \& Dehnavi, (2013), Kabak 
et al.,(2014) and Bektas \& Sohrabifard, (2013) that confirmed the results of this study. Therefore, increasing teamwork will increase the empowerment of the organization under study. Thus, it is suggested that by forming specialized working groups for the purposes of the organization, employees should be encouraged to join these groups according to their interests and their abilities. In addition, organizing workshops for group activities in the organization and familiarizing staff with such activities should be considered.

Finally, in the fifth hypothesis, the relationship between employee training and empowerment was analyzed at the headquarters of the Social Security Organization, which was confirmed. Thus, we concluded a meaningful relationship between employee training and empowerment and that was direct. In confirmation of the acceptance of the hypothesis based on theoretical studies and theoretical knowledge, we made comparisons between the present research and similar studies by Mola, (2015) and Molaei, Goldar, \& Emdadi Far, (2010), Sweis, Mansour, Tarawneh, \& Dweik, (2013), Hanaysha,(2015) which confirmed the results of this study. Regarding the confirmation of the effect of employee training on employee empowerment, suggestions are presented as follows:

Conducting scientific, educational and scientific seminars and conferences in cooperation with scientific centers and universities and collecting articles from among the staff of the organization and disseminating the achievements and suggestions in the organization.

-Publishing and distributing scientific and specialized journals and publications or internal bulletins focusing on staff training to empower them and improve their educational activities.

- Creating a website with the goal of providing virtual and accessible training for staff and training staff members in the organization's goals in the form of videos and slides

\section{Reference}

Abtahi, H. (1994). Training and human resource development. 2 Edit Tehran: Institute for Educational Studies and Planning Organization

Adesola, M., Oyeniyi, K., \& Adeyemi, M. (2013). Empirical Study of the Relationship between Staff Training and Job Satisfaction among Nigerian Banks Employees. International Journal of Academic Research in Economics and Management Sciences, 2(6), 108-115. https://doi.org/10.6007/IJAREMS/v2-i6/446

Arefi, M., Shuhudi, M., \& Zandi, K. (2012). The Correlation between Organizational citizenship behavior and Teamwork (A case study of university employees Kurdistan). Quarterly Journal of Career \& Organizational Counseling, 4(12), 31-49.

Askarzadeh, H., \& Dehnavi, M. (2013). The relationship between employee empowerment and staff working skills. Conference on Management, Entrepreneurship and Economic Development, Qom,. $\quad$ Retrieved from https://www.civilica.com/Paper-EME02-EME02_378.html

Avery, R. E., Smillie, L. D., \& Fife-Schaw, C. R. (2015). Employee achievement orientations and personality as predictors of job satisfaction facets. Personality and Individual Differences, 
76, 56-61. https://doi.org/10.1016/j.paid.2014.11.037

Baker, D., Horvath, L., Campion, M., \& Salas, E. (2005). The ALL Teamwork Framework. International Adult Literacy Survey, Measuring Adult Literacy and Life Skills: New Frameworks for Assessment, 13, 229-272. Retrieved from http://scholar.google.com/scholar?hl=en\&btnG=Search\&q=intitle:Teamwork+:+Status+Mem orandum\#0

Baker, D. P., Amodeo, A. M., Krokos, K. J., Slonim, A., \& Herrera, H. (2010). Assessing teamwork attitudes in healthcare: development of the TeamSTEPPS teamwork attitudes questionnaire. Quality \& Safety in Health Care, 19(6), e49. https://doi.org/10.1136/qshc.2009.036129

Bakotić, D., \& Babić, T. (2013). Relationship between Working Conditions and Job Satisfaction: The Case of Croatian Shipbuilding Company. In International Journal of Business and Social Science (Vol. 4). Retrieved from www.ijbssnet.com

Baloh, P., \& Trkman, P. (2003). Influence of Internet and Information Technology on Work and Human Resource Management. Proceedings of the 2003 InSITE Conference. https://doi.org/10.28945/2642

Bektas, C., \& Sohrabifard, N. (2013). Terms of Organizational Psychology, Personnel Empowerment and Team Working: A Case Study. Procedia - Social and Behavioral Sciences. https://doi.org/10.1016/j.sbspro.2013.06.366

Bin Abdullah, R., Musa, M., Zahari, H., Rahman, R., \& Khalid, K. (2011). The Study of Employee Satisfaction and its Effects towards Loyalty in Hotel Industry in Klang Valley, Malaysia. In International Journal of Business and Social Science (Vol. 2). Retrieved from www.ijbssnet.com

Bowen, D. E., \& Lawler, E. E. (1992). The empowerment of service workers: what, why, how, and when. Sloan Management Review, 33(3), 31-39. Retrieved from http://www.ncbi.nlm.nih.gov/pubmed/10118526

Chen, M. L., Su, Z. Y., Lo, C. L., Chiu, C. H., Hu, Y. H., \& Shieh, T. Y. (2014). An empirical study on the factors influencing the turnover intention of dentists in hospitals in Taiwan. Journal of Dental Sciences. https://doi.org/10.1016/j.jds.2013.01.003

Dabaghi, P., Taqhva, A., Minaashiri ,K. (2014). The Relationship between Psychological Potential and Job Satisfaction in Different Military Forces. Ibn Sina - Medical Quarterly, 15 (3), 18-26.

Eidipour, T., \& Zarei, R. (2016). Investigating the relationship between human resource empowerment and job satisfaction among staff at the General Directorate of Education in Fars province. Proceedings of the International Conference on Management and Dynamic Economics, Iran-Malaysia. $\quad$ Retrieved from https://www.civilica.com/Paper-MDEHAMAYESH01-MDEHAMAYESH01_196.html

Fapohunda, T. M. (2013). Towards Effective Team Building in the Workplace. International 
Journal of Education and Research, 1(4). Retrieved from www.ijern.com

Fiori, M., Bollmann, G., \& Rossier, J. (2015). Exploring the path through which career adaptability increases job satisfaction and lowers job stress: The role of affect. Journal of Vocational Behavior, 91, 113-121. https://doi.org/10.1016/j.jvb.2015.08.010

Hair, J. F., Black, W. C., Babin, B. J., Anderson, R. E. (2014). Multivariate Data Analysis,. In Pearson New Internathional Edition (Seventh Ed). https://doi.org/10.1007/978-3-319-01517-0_3

Hanaysha, J. (2015). Testing the Effects of Employee Empowerment, Teamwork, and Employee Training on Employee Productivity in Higher Education Sector. International Journal of Learning \& Development, 6(1), 164-178. https://doi.org/10.5296/ijld.v6i1.9200

Hanaysha, J., \& Tahir, P. R. (2016). Examining the Effects of Employee Empowerment, Teamwork, and Employee Training on Job Satisfaction. Procedia - Social and Behavioral Sciences, 219, 272-282. https://doi.org/10.1016/j.sbspro.2016.05.016

Hoegl, M., \& Gemuenden, H. G. (2001). Teamwork Quality and the Success of Innovative Projects: A Theoretical Concept and Empirical Evidence. Organization Science, 12(4), 435-449. https://doi.org/10.1287/orsc.12.4.435.10635

Hoegl, M., \& Parboteeah, K. P. (2007). Creativity in innovative projects: How teamwork matters. Journal of Engineering and Technology Management, 24(1-2), 148-166. https://doi.org/10.1016/j.jengtecman.2007.01.008

Hu, L., \& Bentler, P. M. (1999). Cutoff criteria for fit indexes in covariance structure analysis: Conventional criteria versus new alternatives. Structural Equation Modeling: A Multidisciplinary Journal, 6(1), 1-55. https://doi.org/10.1080/10705519909540118

Kabak, K. E., Şen, A., Göçer, K., Küçüksöylemez, S., \& Tuncer, G. (2014). Strategies for Employee Job Satisfaction: A Case of Service Sector. Procedia - Social and Behavioral Sciences, 150, 1167-1176. https://doi.org/10.1016/j.sbspro.2014.09.132

Khuong, M. N., \& Tien, B. D. (2013). Factors influencing employee loyalty directly and indirectly through job satisfaction - A study of banking sector in Ho Chi Minh City. International Journal of Current Research and Academic Review, 1(4), 81-95. Retrieved from www.ijcrar.com

Lencioni, P. (2002). The Five Dysfunctions of a Team: A Leadership Fable. In San Francisco, CA: Jossey-Bass. https://doi.org/10.1108/k.2011.06740aae.002

McLagan, P. A., \& Nel, C. (1995). The age of participation: new governance for the workplace and the world. Berrett-Koehler.

Mihm, J. C. (2001). HUMAN CAPITAL Practices That Empowered and Involved Employees. Retrieved from https://www.gao.gov/products/GAO-01-1070

Mirzai, H., \& Fathi, L. (2013). Study of Job Satisfaction of Employees of East Azarbaijan Gas Company. Sociological Studies, 5(18), 137-151. 
Mola, M. A. (2015). The Effect of In-Service Training on Empowerment of managers of Jihad-e-Agriculture Organization. Urmia University,Faculty of Literature and Human Sciences.

Molaei, N., Goldar, Z., \& Emdadi Far, O. (2010). Investigating the relationship between in-service training and the dimensions of human resource empowerment. Management and Human Resources in the Summer Oil Industry, 11, 56-67.

Moradi, M., \& Ali, A. (2016). Psychological empowerment with self-efficacy. Cheshm Andaze Ghotb.

Mousavi, S. (2009). The Effect of Human Resources Training on Job Satisfaction and Productivity of Employees in Special Economic Zone Organization of Pars Asalouyeh. Master's Thesis. Islamic Azad University of Marvdasht Branch

Nadler, L. (1984). The Handbook of human resource development. Hoboken, NJ: John Wiley \& Sons.

Nagendra, A., \& Deshpande, M. (2014). Human Resource Information Systems (HRIS) in HR Planning and Development in Mid to Large Sized Organizations. Procedia - Social and Behavioral Sciences. https://doi.org/10.1016/j.sbspro.2014.04.169

Pan, F. C. (2015). Practical application of importance-performance analysis in determining critical job satisfaction factors of a tourist hotel. Tourism Management, 46, 84-91. https://doi.org/10.1016/j.tourman.2014.06.004

Robbins, T., Crino, M., \& Fredendall, L. (2003). An integrative model of the empowerment process. Human Resource Management Review. https://doi.org/10.1016/s1053-4822(02)00068-2

Schmidt, S. W. (2004). Job Training and Job Satisfaction Survey Running head: JOB TRAINING AND JOB SATISFACTION SURVEY The Job Training and Job Satisfaction Survey Technical Manual ,Online Submission (p. 36). p. 36. Retrieved from https://eric.ed.gov/?id=ED494451

Sepehr, F., \& Vesal Azad, R. (2016). The Relationship Between Web Therapy and Empowerment of Library Librarians of Iran University of Medical Sciences and Health Services. 2nd International Conference on Web Research, 203-217.

Sharafi, M., \& Bahar, M. (2016). Comparative study on the effect of in-service training on satisfaction of educational needs and job satisfaction among teachers in Iran and Germany. New Approach in Educational Management, 7(1), 45-21

Singh, T. (2016). Conceptualising the Antecedents and Consequences of Psychological Empowerment in Service Sector. International Journal of Applied Research and Studies, 5(4). https://doi.org/10.20908/ijars.v5i4.10122

Soltani, M. S. (2016). Investigating employee empowerment and improvement of teamwork in the Kurdistan Power Distribution Company. Journal of Management Studies and 
Accounting, 2(1), 63-74.

Sultana, A., Sobia, I., Ahmed, K., \& Mehmood, N. (2012). Interdisciplinary Journal of Contemporary Research In Business Impact Of Training On Employee Performance: A Study of Telecommunication Sector in Pakistan. Interdisciplinary Journal of Contemporary Research In Business, 4(6), 646-661.

Sweis, R. J., Mansour, A. Al, Tarawneh, M., \& Dweik, G. Al. (2013). The impact of total quality management practices on employee empowerment in the healthcare sector in Saudi Arabia: a study of King Khalid Hospital. International Journal of Productivity and Quality Management, 12(3), 271. https://doi.org/10.1504/IJPQM.2013.056149

Tabatabaee, S. A. (2004). Training of government employees, Tehran, Publications of Office Development of Management and Human Capital.

Wellins, R. S., Byham, W. C., \& Wilson, J. M. (1991). Empowered teams : creating self-directed work groups that improve quality, productivity, and participation. Jossey-Bass.

Wilson, J. P. (2004). Human Resources Management. Learning and Training for Individuals and Organizations.

Zamani, M., Haghighi, M., Razmjoo, Sh. (2014). The relationship between employee satisfaction, organizational entrepreneurship and organizational growth in insurance companies, organizational culture management, 12(4), 635-653.

\section{Glossary}

TW : Team work

TRA: Training

EMP: Empowerment

JS : Job Satisfaction

\section{Copyright Disclaimer}

Copyright for this article is retained by the author(s), with first publication rights granted to the journal.

This is an open-access article distributed under the terms and conditions of the Creative Commons Attribution license (http://creativecommons.org/licenses/by/4.0/). 